\title{
Metal Pollution and Ecological Risk Assessment in Sediment of Artificial Estuary: Case of Vridi Channel, Côte d'Ivoire \\ ${ }^{1 *}$ YAO, MARCEL KONAN; ${ }^{1}$ BROU, YAPI SERGES; ${ }^{1}$ TROKOUREY, ALBERT; ${ }^{2}$ SORO, MÉTONGO BERNARD
}

\author{
${ }^{1}$ Laboratory of Physical Chemistry. University Félix Houphouët-Boigny of Cocody-Abidjan, (Côte d'Ivoire). B.P. V34 Abidjan, Côte \\ d'Ivoire. \\ ${ }^{2}$ Center of Oceanographic Research, Rue des pêcheurs, BP V 18 Abidjan, Cote d'Ivoire. \\ - Corresponding author: Tél.: +225 07130942/+225 40002725 (Côte d'Ivoire); email : yaomarcelkonan@ gmail.com
}

\begin{abstract}
This study focused on a yearly monitoring of sediment pollution in $\mathrm{Cd}, \mathrm{Co}, \mathrm{Cu}$, $\mathrm{Fe}, \mathrm{Mg}, \mathrm{Mn}, \mathrm{Ni}, \mathrm{Pb}, \mathrm{Zn}$ and the ecological incurred risks in Vridi channel. The results, expressed per dry weight, showed that the annual mean were $0.96( \pm 0.16) \mathrm{mg} / \mathrm{Kg}$ for Cd, 22.36 $( \pm 2.41) \mathrm{mg} / \mathrm{kg}$ for $\mathrm{Co}, 33.98( \pm 4.61)$ for $\mathrm{Cu}, 31760.5( \pm 5652.7) \mathrm{mg} / \mathrm{kg}$ for $\mathrm{Fe}, 981.2 \pm(377.5)$ $\mathrm{mg} / \mathrm{kg}$ for $\mathrm{Mg}, 302.9( \pm 415.4) \mathrm{mg} / \mathrm{kg}$ for $\mathrm{Mn}, 42.53( \pm 9.79) \mathrm{mg} / \mathrm{kg}$ for $\mathrm{Ni}, 83.37( \pm 6.66)$ $\mathrm{mg} / \mathrm{kg}$ for $\mathrm{Pb}$ and 27.11 ( \pm 11.72 ) mg/kg for Zn. The measured oligo-elements (Fe, Mn, Mg, Zn) originated from naturals sources and were away from accumulation, except from Fe which moderately accumulated. That hence the low sediment contamination by these metals. As for toxic trace metal (not essential) to living organisms $(\mathrm{Co}, \mathrm{Cu}, \mathrm{Pb}, \mathrm{Cd}, \mathrm{Ni}$ ), they resulted from anthropogenic origin. These sediments were moderately contaminated in $\mathrm{Co}, \mathrm{Cu}$ and $\mathrm{Ni}$, significantly in $\mathrm{Pb}$ and strongly in $\mathrm{Cd}$. All the studied trace metals were mainly from continental origin, except $\mathrm{Cd}$ which showed a marine origin. This estuary displayed a steady state of progressive deterioration and presented a very high ecological risk. ( $)$ JASEM

https://dx.doi.org/10.4314/jasem.v21i4.20
\end{abstract}

Keywords: Abidjan, Atlantic Ocean, Ebrié System, pollution indicators, trace metals

Vridi channel is the main connection of Ebrié lagoon system to Atlantic Ocean in front of Abidjan. It's known that industrial activities and major factories are located along Ebrié lagoon system, particularly in Abidjan district. Consequently, this estuary is subjected to many terrestrial and marine pollutants, as lagoon bays of Abidjan district (Inza et al., 2014; N'Guessan, 2014; Yao et al., 2009). Specifically, dumping of metal waste is suspected in fish collapse and eutrophication of the Ebrié lagoon. Some trace metals ( $\mathrm{Fe}, \mathrm{Mg}, \mathrm{Zn}, \mathrm{Cu}$, etc.) are fundamental to the physiological development of living organisms. That could sustain the high productivity level in the Ebrié system. If harmfulness to those organisms appears with excessive concentrations (Habib et al., 2016; Zhang et al., 2016; Zheng et al., 2010), many highly toxic metal $(\mathrm{Hg}, \mathrm{Cr}, \mathrm{Cd}$, etc.), even at very low doses, are regularly measured near of this channel (Inza et al., 2014; Yao et al., 2009). These charges are transported through drains, meteoric waters runoff, atmospheric way, rivers, etc., in particulate and/or dissolved forms. Metal undergo irreversible sedimentation through the important mechanism of diagenesis ( $\mathrm{Lu}$ et al., 2014; Prajith et al., 2016; Robbins et al., 2015). However, the required time leads to remobilization by other processes, including bioturbation (He et al., 2015; Remaili et al., 2016). Indeed, the channel is subjected to periodic dredging, pipeline installations, daily passage of ships and other motorized vehicles. Furthermore, several parameters are involved in these processes, including $\mathrm{pH}$, oxygen, salinity, hardness and organic carbon content, which are the most influential physical and chemical parameters in this type of exchange in these entities (Blewett et al., 2016;. Kaplan and Cory, 2016; Lewis et al., 2016; Ritchie and Mekjinda, 2016; Schijif and Zoll, 2011). These ways of contamination are likely to affecting all the entire food chain (Lu et al., 2014; Pradit et al., 2016); and organisms are exposed to many diseases and physiological disorders.

In the context of the sustainable development of Vridi channel, it is important to run monitoring of pollution level. This paper assessed metal pollution in this channel through analysis of concentrations in $\mathrm{Cd}, \mathrm{Cu}$, $\mathrm{Co}, \mathrm{Fe}, \mathrm{Mg}, \mathrm{Mn}, \mathrm{Ni}, \mathrm{Pb}$ and $\mathrm{Zn}$ within three sedimentary fractions. Its ecological risk states were subsequently evaluated with regard to distribution of size of sediments.

\section{MATERIAL AND METHODS}

Study area: Vridi Channel is a manmade estuary in the coastline near the locality of Vridi. It was realized from 1938 to 1950 during the creation of the autonomous harbour of Abidjan. This estuary is located between $4^{\circ} 0^{\prime} 50^{\prime \prime}$ west longitudes to the north latitude $5^{\circ} 15^{\prime} 23^{\prime \prime}$. Its $2.7 \mathrm{~km}$ long with depths ranging from 12 to $25 \mathrm{~m}$. Draughts are estimated to reach 12 $\mathrm{m}$, while her draft air of $11.8 \mathrm{~m}$. Due to the presence of Atlantic Ocean, the watershed of this estuary is invaluable. However, its watershed on the continent is related to that of Ebrie system, which is $93600 \mathrm{~km}^{2}$. Currents are important (about $1.5 \mathrm{~m} / \mathrm{s}$ (Brenon et al., 2008)) and generate two high tides and two low tides daily. At high tides, marine waters rise to Ebrié 
system, while in low tides the opposite happens. Each of its phenomenons is observed for 5 hours during lagoon dry season, and 6 hours during lagoon flood season. These phenomenons occur successively 2 times a day with the observation of an equilibrium state of 1 hour between the marine and lagoon water. To avoid its rapid siltation, this estuary was oriented to the southeast (in the direction of the canyon) at north-west, accentuated by the construction of discarded and wing walls, but also by a carpet fascinage weighted riprap (Monde et al., 2011). Vridi channel is at the intersection of Abidjan district (located on continental) and the department of Jacqueville (on the coast). Thus, the landscape is dominated by metropolis Abidjan on continental, while coastal areas is dominated by coniferous forests, coastal forests, coastal thickets, swampy forests, relics of mangroves that line Ebrié system. Climate is sub-equatorial characterized by four seasons: two dry seasons (December to March and July to September) and two rainy seasons (April to July and September to November). The atmospheric temperature varies between $27^{\circ} \mathrm{C}$ and $35^{\circ} \mathrm{C}$. Temperatures are generally low during rainy season (May to July and November) and at the beginning of main dry season (December-January), and higher during dry seasons (January-April and SeptemberOctober). Annual rainfall in the area varies between 1400 and $2500 \mathrm{~mm}$. This estuary is subject to both marine seasons observed on the coast of Atlantic Ocean in front of Abidjan and Ebrié system seasons. The marine seasons are characterized by 2 dry seasons (little season (November-December) and great season (March to May)) and 2 cold seasons (little season (December-January) and great season (July-October)). Those of Ebrié system are characterized by a dry season (January-April), a rainy season (May-August) and a flood season (SeptemberDecember). It is deduced Vridi channel seasons such as: dry season (February-April), rainy season (MayJuly), great cold season (August-September), flood season (October-November) and little cold season (December-January). The whole area from Ebrié system to Atlantic Ocean is experiences remarkable biodiversity. However, this biodiversity is highly threatened by the heavy pollution encountered by these ecosystems due to strong anthropogenic pressures. This pollution has many origins:

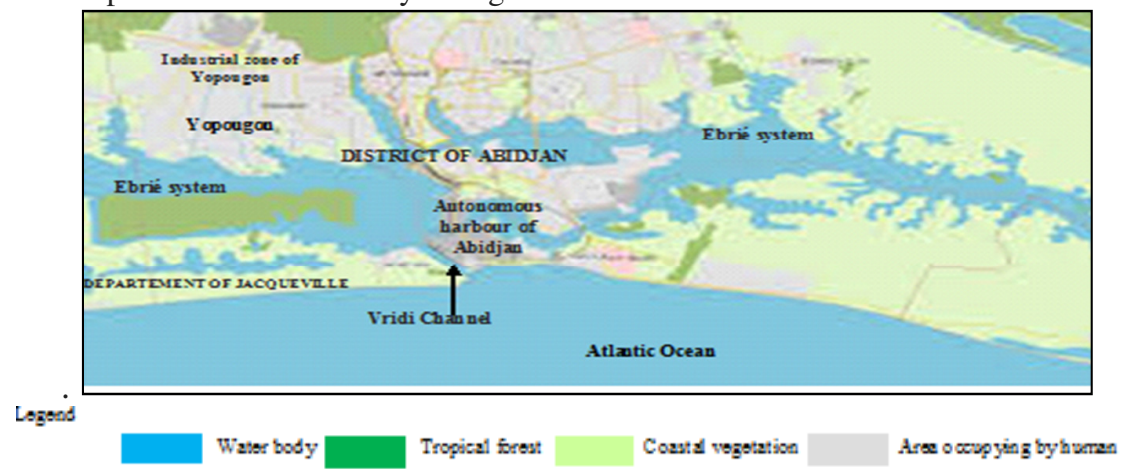

agriculture, industry, land, air, etc. Indeed, the real lack of sanitation infrastructure, the high population growth and the development of human activities in the district of Abidjan are responsible of that situation. Thus, these ecosystems hold receptacle place for pollutants without prior and/or weak treatments, particularly those of the industrial zone of Yopougon (about $30 \mathrm{Km}$ from the Vridi channel) and industrial zone of autonomous harbor neighboring the estuary (Fig.1).

Samples Collection: This study was conducted over one year (April 2014-March 2015). Monthly sampling was done at three stations (Fig.2) and 36 samples were generated. These samples were collected upper $5 \mathrm{~cm}$ of the sediment-bed surface using a Wan-Veen type grab according to AFNOR X 31-100 (1992). Samples were collected in polyethylene bottles and stored in ice.

Samples Preparation: In laboratory, samples, and cleaned coarse elements, were firstly freeze-dried to constant weight according to the AFNOR NF EN ISO 16720 (2007). Then, they were screened through a sieve diameter equal to $2 \mathrm{~mm}$ according to AFNOR NF X 31-107 (2003). Sub-samples were put in dry and clean polyethylene bottled, finally stored in dark and cool $\left(20^{\circ} \mathrm{C}\right)$ place for further analysis.

Samples analysis: Determination of size and distribution of sediments and their total content of $\mathrm{Cd}, \mathrm{Cu}, \mathrm{Co}, \mathrm{Fe}, \mathrm{Mg}, \mathrm{Mn}, \mathrm{Ni}, \mathrm{Pb}$ and $\mathrm{Zn}$ was conducted. These measurements were made on three fractions of these sediments: fraction I (diameter $>$ $250 \mu \mathrm{m})$, fraction II $(0.63 \mu \mathrm{m}<$ diameter $<250 \mu \mathrm{m})$ and fraction III (diameter $<0.63 \mu \mathrm{m}$ ). The determination of distribution of particle size was performed in accordance with AFNOR NF X 31-107 (2003). Cd, Co, Cu, Fe, Mn, $\mathrm{Ni}, \mathrm{Pb}$ and $\mathrm{Zn}$ were determined according to AFNOR NF T90-112 (1986), and $\mathrm{Mg}$ following AFNOR NF T 90-005 (1986). These analyzes were performed in triplicate. Metal concentrations were measured using an airacetylene flame using atomic absorption spectrophotometer VARIAN AA 1275. 
Fig.1: Presentation of study area

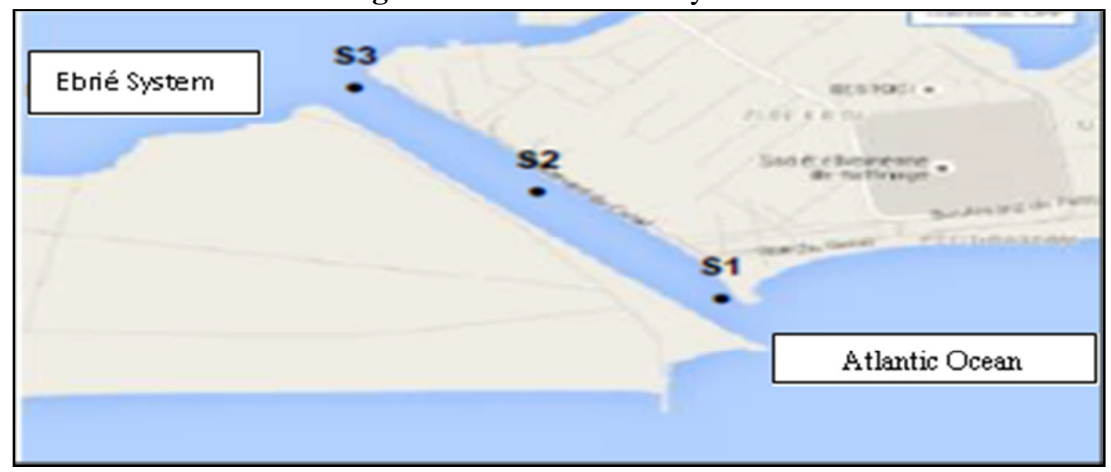

Fig. 2: Location of the sampling sites in Vridi channel

Data evaluation: The assessment of metal pollution level in sediments of Vridi channel was done taking into account 4 pollution indicators: the index of geo accumulation (Igeo), the contamination factor $(\mathrm{CF})$, the enrichment factor (EF) and the pollution load index (PLI).

Regarding Igeo, it gives an estimate of accumulation level of trace metals in sediments (Ghani, 2015; Böddeker et al., 2017). Defined by Müller (1981), it is obtained using the following formula:

$$
I_{\text {géo }}=\log 2\left(\frac{C_{m}}{1,5 \times C_{B}}\right)(I)
$$

with:

- Cm, concentration of metals in sediment $(\mathrm{mg} / \mathrm{Kg})$;

- $\mathrm{C}_{\mathrm{B}}$, value of the geochemical background noise for the metal $(\mathrm{mg} / \mathrm{Kg})$;

- 1.5 , constantly taking account of natural fluctuations in the content of a substance in environmental and anthropogenic variations.

Depending on the value of Igeo, it is defined the class and contamination level. This classification is as follows:

- Class (0) $($ Igeo < 0), uncontaminated;

- Class $(1)(0<$ Igeo $<1)$, uncontaminated to moderately contaminated);

- Class (2) $(1<$ Igeo < 2), moderately contaminated;

- Class (3) $(2<$ Igeo $<3)$, moderately contaminated to severely contaminated;

- Class (4) $(3<$ Igeo $<4)$, severely contaminated;

- Class $(5)(4<$ Igeo $<5)$, severely contaminated to extremely contaminated;

- Class (6) (Igeo < 5) extremely contaminated.

As regards the contamination factor $(\mathrm{CF})$, it is possible to know metal contamination level of sediments (Nadem et al., 2015, Ali et al., 2016; Islam et al., 2015). It is calculated from the following relationship:

$$
\mathrm{CF}=\frac{\mathrm{C}_{\mathrm{m}}}{\mathrm{C}_{\mathrm{B}}}(\mathrm{II})
$$

The different contamination levels based on CF values are defined as follows:

- $\mathrm{CF}<1$, low contamination;

$-1 \leq \mathrm{CF} \leq 3$, moderate contamination;

$-3 \leq \mathrm{CF} \leq 6$, significant contamination;

$-\mathrm{CF} \geq 6$, very high contamination.

As concern the enrichment factor (EF), it allows to distinguish anthropogenic origins of trace metals to their natural origins (Böddeker et al., 2017; Li et al.; 2017). Developed by Ackerman (1980), it is calculated according to the relation below:

$$
\mathrm{EF}=\frac{([\mathrm{X}] /[\mathrm{R}]) \text { sample }}{([\mathrm{X}] /[\mathrm{R}]) \text { reference material }}
$$

With: $[\mathrm{X}]$, concentration of trace metal; and [R], concentration of normalizing element.

In this study, $\mathrm{Fe}$ was chosen as a reference material because it is mainly natural origin one hand, and it is not influenced by processes which can change its natural contents in sediments in second hand. EF values between 0.5 and 1.5 indicate a naturally occurring metal, while those above 1.5 are attributed to anthropogenic origins (Zheng et al., 2010).

The load index of pollution (PLI) was used as the overall index for the general assessment of metal pollution in sediments of Vridi channel. This index, defined by Tomlinson and al., (1980), is obtained according to (IV):

$$
\mathrm{PLI}=\sqrt[\mathrm{n}]{\mathrm{CF}_{1} \times \mathrm{CF}_{2} \times \mathrm{CF}_{3} \times \ldots \times \mathrm{CF}_{\mathrm{n}}}(\mathrm{IV})
$$

with: $\mathrm{CF}_{\mathrm{i}}$, the contamination factor for trace metal $\mathrm{i}$.

Thus, according to the value of the PLI, it is noted:

- PLI $=0$, no damage;

- PLI $=1$, only the reference levels of pollutants are present;

- PLI > 1 indicates a gradual deterioration of the estuary. 
In the lack of a guide on the contents of these trace metals before the pre-industrial era in Ivoirian surface waters and even on the Gulf of Guinea, the different metal background values (reference) were taken from those provided by Wedepohl (1995) for the upper continental crust.

The ecological risk assessment was evaluated by the potential ecological risk index (PERI). Developed by Hänkson (1980), it is defined by:

$$
\begin{gathered}
\text { PERI }=\sum \mathrm{Er}^{\mathrm{i}}(\mathrm{V}) \\
\mathrm{Er}^{\mathrm{i}}=\operatorname{Tr}^{\mathrm{i}} \times \mathrm{CF}^{i}(\mathrm{VI})
\end{gathered}
$$

with:

- $\mathrm{Er}^{\mathrm{i}}$, is the monomial potential ecological risk factor;

- $\mathrm{TR}^{\mathrm{i}}$ is the toxic-response factor for a given substance $(\mathrm{Cu}=\mathrm{Pb}=\mathrm{Ni}=5, \mathrm{Zn}=1, \mathrm{Cd}=30)$; - $\mathrm{CF}^{\mathrm{i}}$, obtained following (II).

According PERI value, it is obtained the potential ecological risk of the sediment. So, if:

- PERI < 150, low ecological risk for the sediment;

- $150 \leq$ PERI < 300, moderate ecological risk for the sediment;

- $300 \leq$ PERI < 600, considerable ecological risk for sediment;

- PERI $\geq 600$, very high ecological risk for the sediment.

This index is calculated with trace metals which have anthropogenic origin (Effendia et al., 2016; Nadem et al., 2015; Ali et al. 2016).

\section{RESULTS AND DISCUSSION}

Sediments have a decreasing particle size distribution from the station S1 to the station S3 (Fig.3). Sediments of the station S1 compounds were: (2.99 \pm $1.51) \%$ of rudites, $(92.19 \pm 12.50) \%$ of sand and $(4.82 \pm 0.41) \%$ of silt. Those in the station S2 were: $(5.43 \pm 2.72) \%$ of rudites, $(79.90 \pm 8.09) \%$ of sand and $(14.67 \pm 0.50) \%$ of silt. As regards the sediments of the station S3, their compositions were: $(0.77 \pm$ $0.39) \%$ of rudites, $(52.43 \pm 4.38) \%$ of sand and $(46.80 \pm 1.05) \%$ of silt. So, sediments of Vridi channel are sandy texture. Qualitative analysis of sediments in the estuary highlighted its slow siltation as designed in its realization. Indeed, it was noted an almost non mixing marine sediments (mainly sand Marine 50 Quaternary (sandy texture of very rough and coarse) (Wagner, 2002)) to the station S1 with lagoon sediments (coarse sand and silt from meteorites contributions, wastewater discharges, organic matter from detritus terrigenous particles and/or plant debris) to stations S2 and S3. Due to its orientation, the contribution of marine sediments from Atlantic Ocean are most hampered by the canyon and finally stopped by discarded and wing walls just after the station $\mathrm{S} 1$; while those from continental will first settle in the lagoon area of the harbor and later stopped (mostly in the form of coarse and medium sands) by discarded and wing walls at the station S2. This would explain the decrease in distribution of the particle size from the station $\mathrm{S} 1$ to the station $\mathrm{S} 3$.

Results from trace metals studies are presented in Table 1. Fe showed the highest annual mean value and $\mathrm{Cd}$ the lowest annual mean value at all stations and within various fractions. In the different sampling stations, the decreasing order of annual mean values of trace metals evaluated was:

$$
\mathrm{Fe}>\mathrm{Mg}>\mathrm{Mn}>\mathrm{Pb}>\mathrm{Ni}>\mathrm{Cu}>\mathrm{Zn}>\mathrm{Co}>\mathrm{Cd}
$$

Most of these trace metals exhibited their high annual mean value in the station $\mathrm{S} 3$, expect those of $\mathrm{Cd}$ in the station S1, Mn and Fe in the station S2. Annual variations were marked ( $\mathrm{VC}>50 \%$ ) for $\mathrm{Cd}, \mathrm{Cu}, \mathrm{Mn}$ in all the sampling stations, $\mathrm{Mg}$ and $\mathrm{Co}$ in stations $\mathrm{S} 2$ and $\mathrm{S} 3$, and $\mathrm{Fe}$ in the station $\mathrm{S} 1$. Except $\mathrm{Cd}$, which has a relatively low variation of annual mean values from one station to another $(<0.1 \mathrm{mg} / \mathrm{kg}$ dry weight $)$, those of other trace metals were relatively higher. For fractions considered in this study, the decreasing order of annual mean values of trace metals evaluated as follows:

$$
\begin{aligned}
& \text { - Fraction I: } \mathrm{Fe}>\mathrm{Mg}>\mathrm{Mn}>\mathrm{Pb}>\mathrm{Cu}>\mathrm{Ni}>\mathrm{Zn}> \\
& \qquad \mathrm{Co}>\mathrm{Cd} \text {; } \\
& \text { - Fraction II: } \mathrm{Fe}>\mathrm{Mg}>\mathrm{Mn}>\mathrm{Pb}>\mathrm{Ni}>\mathrm{Co}>\mathrm{Cu}> \\
& \text { Zn }>\mathrm{Cd} \text {; } \\
& \text { - Fraction III: } \mathrm{Fe}>\mathrm{Mg}>\mathrm{Mn}>\mathrm{Pb}>\mathrm{Zn}>\mathrm{Ni}>\mathrm{Cu}> \\
& \text { Co }>\mathrm{Cd} .
\end{aligned}
$$

$\mathrm{Fe}, \mathrm{Mn}$ and $\mathrm{Cu}$ showed their maximum annual mean value in the fraction I and that of $\mathrm{Ni}$ in the fraction II. As concerned $\mathrm{Cd}, \mathrm{Zn}, \mathrm{Pb}, \mathrm{Mg}$ and $\mathrm{Co}$, their maximum annual mean value was observed in fraction III. Annual variations are important (VC > $50 \%$ ) for $\mathrm{Cd}$ and $\mathrm{Mn}$ in the fraction $\mathrm{I}$, for $\mathrm{Mn}$ in fraction II, for $\mathrm{Cd}, \mathrm{Ni}$ and $\mathrm{Mg}$ in the fraction III. Variations of annual mean values for these trace metals were relatively important. Referring to the Müller criteria (1981), it is noted that only Cd accumulated moderately $(1<$ Igeo $<2)$ within the sediments of Vridi channel; while $\mathrm{Co}, \mathrm{Pb}, \mathrm{Ni}, \mathrm{Cu}$ and Fe tend to accumulate moderately $(0<$ Igeo $<1)$. Mg, $\mathrm{Mn}$ and Zn didn't accumulate (Igeo < 0 ). Contamination of these sediments in $\mathrm{Cd}(\mathrm{CF} \geq 6)$ was extremely important and those of $\mathrm{Pb}$, considerable ( 3 $\leq \mathrm{FC} \leq 6)$ in all sampling stations. These sediments were moderately contaminated $(1 \leq \mathrm{CF} \leq 3)$ in $\mathrm{Ni}$, $\mathrm{Cu}$, Co within all sampling sites, and by $\mathrm{Fe}$ in the station 2. As regard that binds to $\mathrm{Mg}, \mathrm{Mn}, \mathrm{Zn}$ in all sampling stations and $\mathrm{Fe}$ in stations $\mathrm{S} 2$ and $\mathrm{S} 3$, it is moderate. As concerned $\mathrm{EF}$ values obtained for these trace metals, it deduces that $\mathrm{Cd}, \mathrm{Pb}, \mathrm{Ni}$, Co have anthropogenic origin $(\mathrm{EF}>1.5)$ and $\mathrm{Mn}, \mathrm{Mg}, \mathrm{Fe} \mathrm{Zn}$ 
natural origin. All values of PLI and PLI' obtained in all sampling station are greater than 1 (Table 2). So, this estuary is in a gradual degradation state. The mean value of PERI in Vridi channel is 828.2, with that of stations S1, S2 and S3 of 812.3, 741.6 and 930.3 respectively. Therefore sediments Vridi channel has a very high environmental risk referring classification established by Hänkson (1980).

Thus, Vridi channel is subjected to a relatively low contamination by these trace metals, except those for $\mathrm{Cd}$ and $\mathrm{Pb}$. The anthropogenic pressures on the estuary would be relatively less important. This seems contradictory when we know the strong anthropogenic pressures on Ebrié system and Atlantic Ocean coasts, especially in front of the district of Abidjan. For illustration, the mean values of trace metals, obtained in Abidjan lagoon bays by Yao et al., (2009) and Inza et al., (2014), are significantly higher than those obtained in this study. Bathymetry and the hydrodynamics of the estuary would explain this contradictory fact. Indeed, the shallow depth and low hydrodynamics of the Ébrié system would favor trace metals accumulation, in addition to physical and chemical environmental conditions that contribute to it. However, the high depth and strong hydrodynamics in Vridi channel, compared to that of Ebrié system, disadvantage trace metal accumulation. That would also favor the desorption of trace metals in sediments, as shown by Nan et al., (2016). Except $\mathrm{Cd}$ and $\mathrm{Mn}$ which exhibited their highest annual mean values in stations S1 and S2 respectively, all other trace metals studied have theirs in the station S3. This reflects a relatively strong continental contribution compared to that of Atlantic Ocean. The high annual mean values of $\mathrm{Fe}, \mathrm{Mg}$ and $\mathrm{Mn}$ in all stations and fractions illustrate their abundance in the upper crust (Wedepohl, 1995), especially in the continental shelf, the sedimentary basin and the coast of Gulf of Guinea. These trace metals are transported by meteorites continental contributions via Ebrié system in the form of coarse and medium coarse sands. As for the strong presence of $\mathrm{Pb}$, observed after those of $\mathrm{Fe}, \mathrm{Mn}$ and $\mathrm{Mg}$ in all fractions and stations, it is explained by its strong industrial use, especially in that of the oil industry next to the autonomous harbour of Abidjan. It also comes from the oil and gas wharf installed within this estuary. The strong presence of $\mathrm{Zn}, \mathrm{Cd}$ and $\mathrm{Co}$ in sediments in the form of slits (Fraction III) show that they would come from the organic matter decomposition linked to anthropogenic wastes. This fact seemed to be of particular importance in the lagoon area of the harbour for $\mathrm{Zn}$ and $\mathrm{Co}$ (strong presence at the station $\mathrm{S} 3$ ), and for $\mathrm{Cd}$ (strong presence at the station S1) to the coasts of Atlantic Ocean in front of Abidjan. The strong presence of $\mathrm{Cu}$ in the coarse sand (fraction I) and that of $\mathrm{Ni}$ in coarse and medium sands (fraction II) would show that they come from industrial sources, including those of harbour industrial zone if it is referred their importance to the station S3.

The progressive degradation of this estuary, shown by PLI values in all stations, is mainly due to the strong human pressure exerted on this estuary. This fact was mentioned by Ali et al., (2016), Effendia et al., (2016), Mashiatullah et al., (2013) and Nadem et al., (2015). The strong values of PLI' testify to the strong involvement of industrial discharges in this situation, especially those of industrial zone of the harbour. This is illustrated by the observation of the highest values of PLI and PLI' to the station S3. The immediate consequence is a very high ecological risk presented by this channel, especially its sediments; as specified by the high values of PERI in the sampling station. This state of advanced deterioration of this channel would show those of Ebrié system and the coasts of Atlantic Ocean in front of Abidjan, as shown by Yao et al., (2009) in the specific case of Abidjan lagoon bays.

Conclusion: This work has shown that Vridi channel presents an advanced state of degradation with very high ecological risk, bound to metal pollution particularly by $\mathrm{Pb}$ and $\mathrm{Cd}$. This fact is essentially due to anthropogenic pressures, especially wastes coming from to harbour industrial zone. This situation seemed to be lessened by its strong hydrodynamic and high depth.

If no precautions are taken, the ecological future of this estuary will darken further with regard to population growth and human activities in Abidjan district. This study should be extended to other types of pollutants for a real diagnosis of its pollution state. In the future, it would be necessary to lead important political involvements for safeguarding of this estuary for its sustainable development. 


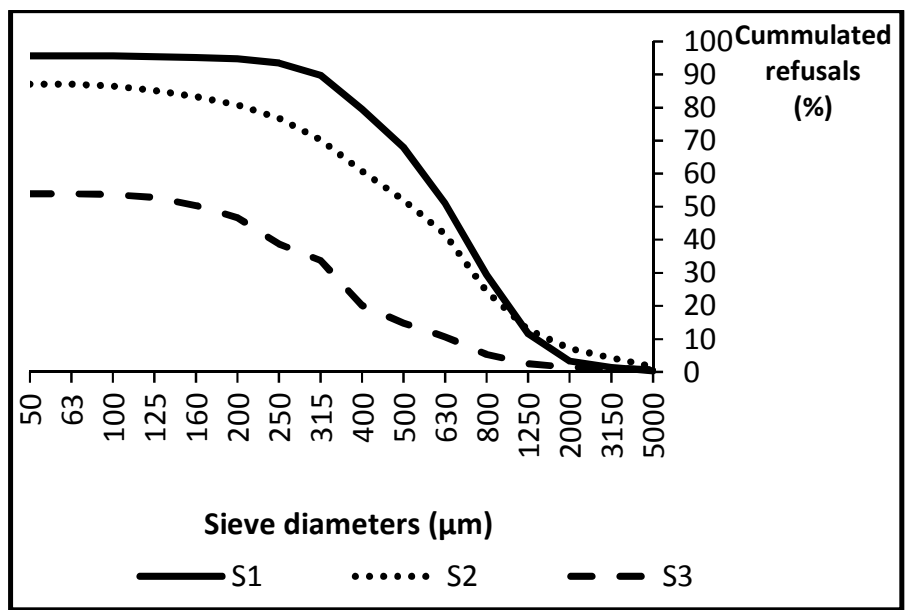

Fig.3: Size distribution of sediments in sampling sites

Table 1: Annual means $( \pm \mathrm{SD})$ of trace metals concentration in fractions and sampling sites

\begin{tabular}{|c|c|c|c|c|c|c|c|}
\hline & \multicolumn{3}{|c|}{ Stations } & \multicolumn{3}{|c|}{ Fractions of sediments } & \multirow[t]{2}{*}{ Annual mean } \\
\hline & S1 & $\mathrm{S} 2$ & S3 & $\bar{I}$ & II & III & \\
\hline $\begin{array}{c}\text { Cd } \\
\text { (mg/Kg per }\end{array}$ & $\begin{array}{l}1.04 \pm 0.95 \\
(90.92 \%)\end{array}$ & $\begin{array}{c}0.89 \pm 0.89 \\
(99.37 \%)\end{array}$ & $\begin{array}{l}0.93 \pm 0.96 \\
(102.68 \%)\end{array}$ & $\begin{array}{c}0.47 \pm 0.29 \\
(62.14 \%)\end{array}$ & $\begin{array}{c}0.37 \pm 0.02 \\
(5.03 \%)\end{array}$ & $\begin{array}{c}2.03 \pm 0.01 \\
(0.45 \%)\end{array}$ & $\begin{array}{c}0.96 \pm 0.16 \\
(16.64 \%)\end{array}$ \\
\hline $\begin{array}{c}\mathrm{Zn} \\
\text { (mg/Kg per } \\
\text { dry weight) }\end{array}$ & $\begin{array}{c}25.05 \pm 12.16 \\
(48.56 \%)\end{array}$ & $\begin{array}{c}23.14 \pm 23.17 \\
(100.16 \%)\end{array}$ & $\begin{array}{c}33.09 \pm 38.34 \\
(115.86 \%)\end{array}$ & $\begin{array}{c}17.84 \pm 12.94 \\
(62.92 \%)\end{array}$ & $\begin{array}{c}10.60 \pm 4.51 \\
(42.51 \%)\end{array}$ & $\begin{array}{c}52.89 \pm 27.65 \\
(52.34 \%)\end{array}$ & $\begin{array}{c}27.11 \pm 11.72 \\
\quad(43.21 \%)\end{array}$ \\
\hline $\begin{array}{c}\mathrm{Pb} \\
\text { (mg/Kg per } \\
\text { dry weight) }\end{array}$ & $\begin{array}{c}82.21 \pm 17.63 \\
(21.44 \%)\end{array}$ & $\begin{array}{c}76.34 \pm 12.47 \\
(16.33 \%)\end{array}$ & $\begin{array}{c}91.57 \pm 22.07 \\
(24.10 \%)\end{array}$ & $\begin{array}{c}74.28 \pm 1.87 \\
(2.52 \%)\end{array}$ & $\begin{array}{c}84.20 \pm 10.6 \\
(11.94 \%)\end{array}$ & $\begin{array}{c}91.64 \pm 15.08 \\
(16.45 \%)\end{array}$ & $\begin{array}{c}83.37 \pm 6.66 \\
(7.99 \%)\end{array}$ \\
\hline $\begin{array}{c}\mathrm{Ni} \\
\text { (mg/Kg per } \\
\text { dry weight) }\end{array}$ & $\begin{array}{c}41.71 \pm 8.67 \\
(20.79 \%)\end{array}$ & $\begin{array}{c}34.12 \pm 9.48 \\
(27.77 \%)\end{array}$ & $\begin{array}{c}51.76 \pm 10.88 \\
(21.02 \%)\end{array}$ & $\begin{array}{c}39.95 \pm 5.21 \\
(13.04 \%)\end{array}$ & $\begin{array}{c}47.29 \pm 2.14 \\
(4.52 \%)\end{array}$ & $\begin{array}{c}40.35 \pm 20.42 \\
(50.60 \%)\end{array}$ & $\begin{array}{c}42.53 \pm 9.79 \\
(23.02 \%)\end{array}$ \\
\hline $\begin{array}{c}\mathrm{Cu} \\
\text { (mg/Kg per } \\
\text { dry weight) }\end{array}$ & $\begin{array}{c}32.29 \pm 17.16 \\
(53.15 \%)\end{array}$ & $\begin{array}{c}32.52 \pm 19.66 \\
(60.46 \%)\end{array}$ & $\begin{array}{c}37.14 \pm 19.95 \\
(53.72 \%)\end{array}$ & $\begin{array}{c}50.52 \pm 5.21 \\
(13.04 \%)\end{array}$ & $\begin{array}{c}13.91 \pm 1.24 \\
(8.90 \%)\end{array}$ & $\begin{array}{c}37.11 \pm 10.44 \\
(28.12 \%)\end{array}$ & $\begin{array}{c}33.98 \pm 4.61 \\
(13.58 \%)\end{array}$ \\
\hline $\begin{array}{c}\text { Mn } \\
\text { (mg/Kg per } \\
\text { dry weight) }\end{array}$ & $\begin{array}{c}259.1 \pm 158.5 \\
(61.2 \%)\end{array}$ & $\begin{array}{c}346.2 \pm 209.5 \\
\quad(60.5 \%)\end{array}$ & $\begin{array}{c}303.5 \pm 283.1 \\
(93.2 \%)\end{array}$ & $\begin{array}{c}371.5 \pm 790.9 \\
(212.9 \%)\end{array}$ & $\begin{array}{c}353.2 \pm 662.9 \\
(187.7 \%)\end{array}$ & $\begin{array}{c}184.1 \pm 15.9 \\
(8.6 \%)\end{array}$ & $\begin{array}{c}302.9 \pm 415.4 \\
(137.1 \%)\end{array}$ \\
\hline $\begin{array}{c}\text { Mg } \\
\text { (mg/Kg per } \\
\text { dry weight) }\end{array}$ & $\begin{array}{c}793.1 \pm 254.1 \\
(32.1 \%)\end{array}$ & $\begin{array}{c}1025.3 \pm 639.5 \\
(63.4 \%)\end{array}$ & $\begin{array}{c}1125.1 \pm 915.9 \\
(81.4 \%)\end{array}$ & $\begin{array}{c}465.4 \pm 230.7 \\
(49.5 \%)\end{array}$ & $\begin{array}{c}840.8 \pm 87.8 \\
(10.5 \%)\end{array}$ & $\begin{array}{c}1637.3 \pm 801.3 \\
(52.6 \%)\end{array}$ & $\begin{array}{c}981.2 \pm 377.5 \\
\quad(38.5 \%)\end{array}$ \\
\hline $\begin{array}{c}\text { Co } \\
\text { (mg/Kg per } \\
\text { dry weight) }\end{array}$ & $\begin{array}{c}21.28 \pm 0.83 \\
(3.89 \%)\end{array}$ & $\begin{array}{c}19.43 \pm 9.80 \\
(50.45 \%)\end{array}$ & $\begin{array}{c}26.37 \pm 18.37 \\
(69.62 \%)\end{array}$ & $\begin{array}{c}15.42 \pm 5.24 \\
(34.01 \%)\end{array}$ & $\begin{array}{c}18.92 \pm 1.73 \\
(9.18 \%)\end{array}$ & $\begin{array}{c}32.76 \pm 0.64 \\
(1.95 \%)\end{array}$ & $\begin{array}{c}22.36 \pm 2.41 \\
(10.75 \%)\end{array}$ \\
\hline $\begin{array}{c}\text { Fe } \\
\text { (mg/Kg per } \\
\text { dry weight) }\end{array}$ & $\begin{array}{c}26903.2 \\
\pm 16385.8 \\
(60.9 \%)\end{array}$ & $\begin{array}{c}35201.8 \\
\pm 14657.3 \\
(41.6 \%)\end{array}$ & $\begin{array}{c}33176.4 \\
\pm 13031.1 \\
(39.3 \%)\end{array}$ & $\begin{array}{c}40559.3 \\
\pm 15757.7 \\
(38.8 \%)\end{array}$ & $\begin{array}{l}20773.8 \\
\pm 4454.5 \\
(21.5 \%)\end{array}$ & $\begin{array}{l}33948.4 \\
\pm 9911.9 \\
(29.2 \%)\end{array}$ & $\begin{array}{l}31760.5 \\
\pm 5652.7 \\
(17.8 \%)\end{array}$ \\
\hline
\end{tabular}

*in bracket, the variation coefficient (VC)

Table 2: Pollution index evaluated in all sampling sites

\begin{tabular}{|c|c|c|c|c|c|c|c|c|c|c|}
\hline & & Cd & $\mathbf{Z n}$ & $\mathbf{P b}$ & $\mathbf{N i}$ & $\mathrm{Cu}$ & Mn & Mg & $\begin{array}{l}\text { Co } \\
\end{array}$ & $\mathrm{Fe}$ \\
\hline \multirow{3}{*}{ Igeo } & S1 & 1.14 & -0.19 & 0.81 & 0.48 & 0.48 & -0.18 & -1.11 & 0.39 & 0.06 \\
\hline & S2 & 1.07 & -0.23 & 0.78 & 0.39 & 0.48 & -0.06 & -0.99 & 0.35 & 0.18 \\
\hline & S3 & 1.09 & -0.07 & 0.86 & 0.57 & 0.54 & -0.11 & -0.95 & 0.53 & 0.16 \\
\hline \multirow{3}{*}{ CF } & S1 & 10.24 & 0.48 & 4.85 & 2.24 & 2.26 & 0.49 & 0.06 & 1.83 & 0.87 \\
\hline & S2 & 8.77 & 0.44 & 4.49 & 1.83 & 2.27 & 0.66 & 0.08 & 1.68 & 1.14 \\
\hline & S3 & 9.14 & 0.67 & 5.39 & 2.78 & 2.60 & 0.58 & 0.08 & 2.53 & 1.07 \\
\hline \multirow{3}{*}{ EF } & S1 & 11.76 & 0.55 & 5.55 & 2.57 & 2.59 & 0.56 & 0.07 & 2.11 & \\
\hline & S2 & 7.70 & 0.39 & 3.94 & 1.61 & 1.99 & 0.58 & 0.07 & 1.47 & \\
\hline & S3 & 8.51 & 0.59 & 5.02 & 2.59 & 2.42 & 0.54 & 0.08 & 2.36 & \\
\hline \multirow{3}{*}{ PLI } & S1 & & & & & 1,21 & & & & \\
\hline & S2 & & & & & 1,24 & & & & \\
\hline & S3 & & & & & 1,46 & & & & \\
\hline \multirow{3}{*}{ *PLI' } & S1 & & & & & 21.45 & & & & \\
\hline & S2 & & & & & 16.59 & & & & \\
\hline & S3 & & & & & 30.02 & & & & \\
\hline
\end{tabular}

*calculated with trace metals from anthropogenic origin 


\section{REFERENCES}

AFNOR NF EN ISO 16720, (2007). Qualité du solprétraitement des échantillons par lyophilisation pour analyse subséquente. Mai 2007, France.

AFNOR NF X 31-107, (2003). Qualité du solDétermination de la distribution granulométrique des particules du sol. Septembre 2003, France.

AFNOR NF T 90-112 (1986). Dosage des éléments métalliques par spectroscopie d'absorption atomique dans la flamme. Sptembre 1986, France.

AFNOR NF T 90-005 (1986). Dosage du calcium et du magnésium par spectroscopie d'absorption atomique dans la flamme. Mars 1986, France.

AFNOR X 31-100, (1992). Qualité des solséchantillonnage, méthode de prélèvement d'échantillons de sols. Décembre 1992, France.

Ackerman, F (1980). A procedure for correcting grain size effect in heavy metal analysis of estuarine and coastal sediments. Environ. Tech. Lett., 1: 518-257.

Ali, MM; Ali, ML; Islam, MS; Rahman, MZ (2016). Preliminary assessment of heavy metals in water and sediment of Karnaphuli River, Bangladesh. Environ. Nanotechnol. Monitor Manag. 5:27-35.

Blewett, TA; Wood, CM; Glover, CN (2016). Salinity-dependent nickel accumulation and effects on respiration, ion regulation and oxidative stress in the galaxias fish, galaxias maculatus. Environ. Pollut. 214 : 132-147.

Böddeker, SC; Hoelzmann, P; Thuyên, LE; Huy, HC; Nguyen, HA; Richter, O; Schwalb, A (2017). Ecological risk assessment of a coastal zone in Southern Vietnam: Spatial distribution and content of heavy metals in water and surface sediments of the Thi Vai Estuary and Can Gio Mangrove Forest. Mar. Pollut. Bull. 114 (2): 1141-1151.

Brenon, I. ; Audouin, O ; Pouvreau, N ; Maurin, J-C (2008). Impact of vertical structure of water mass circulation in tropical lagoon (Ebrié, Ivory Coast). J. Afr. Earth Sci. 55: 47-51.

Effendia, H; Kawaroeb,M; Mursalina, Lestaria, DF (2016). Ecological risk assessment of heavy metal pollution in surface sediment of Mahakam Delta, East Kalimantan. Procedia Environ. Sci. 33: $574-582$.
Ghani, SAA (2015). Trace metals in seawater, sediments and some fish species from Marsa Matrouh Beaches in north-western Mediterranean coast, Egypt. Egypt. J. Aquat. Res. 41: 145-154.

Habib, MR; Mohamed, LAH; Osman, GY; Moussalem, HS;El-Din, ATS; Croll, RP (2016). Biophalaria alexandrina as a bioindicator of metal toxicity. Chemosphere 157: 97-106.

Häkanson, L (1980). An ecological risk index for aquatic pollution control: A sedimentological approach. Wat. Res. 14: 975-1001.

He, Y; Men, B; Yang, X; Wang, D (2015). Bioturbation/bioirrigation effect on thallium released from reservoir sediment by different organism type. Sci. Tot. Environ. 532: 617-624.

Helali, MA; Oueslati,W; Zaaboub, N; Added, A; Aleya, L (2016). Chemical speciation of Fe, Mn, $\mathrm{Pb}, \mathrm{Zn}, \mathrm{Cd}, \mathrm{Cu}, \mathrm{Co}, \mathrm{Ni}$ and $\mathrm{Cr}$ in the suspended particulate matter the Medjerdariver delta (Gulf of Tunis, Tunisia). J. Afri. Earth Sci. 118: 35-44.

Inza, B; Yao, KM; Etchian, AO; Soro, MB; ,Trokourey, A; Bokra, Y (2014). Heavy metals pollution in bottom surface sediments, and metal fluxes through the sediment/ water interface, Milliardaires bay, Ebrie lagoon (Côte d'Ivoire). Academ. J. Environ. Sci. 2 (5): 063-073.

Islam, MS; Ahmed, MK; Habibullah-Al-Mum, M; Hoque, MF (2015). Preliminary assessment of heavy metal contamination in surface sediments from a river in Bangladesh. Environ. Earth Sci. 73:1837-1848.

Kaplan, LA; Cory, RM (2016). Chapter 6-Dissolved organic matter in stream ecosystems: forms, functions, and fluxes of watershed tea. In Elseiver (ed) Stream Ecosystems in a Changing Environment, p. 241-320.

Lewis, A; King, CK; Hill, NA; Cooper, A; Townsend, AT; Mondon, JA (2016). Seawater temperature effect on metal accumulation

and toxicity in subantarctic Macquarie Island Isopod, exosphere gigas. Aquatic Toxicol. 177: 333-342.

Li, H; Ye, S; Ye, J; Fan, J; Gao, M; Guo, H (2017). Baseline survey of sediments and marine organisms in Liaohe Estuary: Heavy metals, polychlorinated biphenyls and organochlorine pesticides. Mar. Pollut. Bull. 114 (1): 555-563. 
Lu, X; Zhang, Y; Liu, H; Xing, M; Shao, X; Zhao, F; Li, X; Liu, Q; Yu, D; Yuan, X; Yuan, M (2014). Influence of early diagenesis on the vertical distribution of metal forms in sediments of Bohai Bay, China Mar. Pollut. Bull. 88 (1-2): 155-161.

Mashiatullah, A; Chaudhary, MZ; Ahmad, N; Javed, T; Ghaffar, A (2013). Metal pollution and assessment in marine sediment of Karachi Coast, Pakistan. Environ. Monotoring Assess. 185 (2): 1555-1565.

Monde, S ; Coulibaly, AS ; Wognin, VAI; Brenon, I; Aka, K (2011). Modélisation hydrologique d'une lagune tropicale à deux exutoires (lagune Ébrié, Côte d'Ivoire) durant la crue exceptionnelle du fleuve Comoé. J Environ Hydrol 19: 1-13.

Müller, G (1981). Die Schwermetallbelastung der sediment des Neckars und seiner Nebenflusse: eine Bestandsaufnahme. Chem Ztg 105: 157-164.

Nan, G; Peifang, W; Chao, W; Jun, H; Jin, Q; Lingzhan, M (2016). Mechanisms of cadmium accumulation (adsorption and absorption) by the freshwater bivalve Corbicula fluminea under hydrodynamic conditions. Environ. Pollut. 212 : $550-558$

N'Guessan, LBK (2014). Contribution à l'étude de la distribution, de la mobilité et de la toxicité potentielle des métaux cuivre, zinc et cadmium dans les sediments d'un estuaire tropical (Côte d'Ivoire). Thèse de doctorat unique, Univ. Félix Houphouët-Boigny. Côte d'Ivoire.

Prajith, A; Purnachandra,VR; Chakraborty, P (2016). Distribution, provenance and early diagenesis of major and trace metals in sediment cores from the Mandovi estuary, western India. Estuar. Coast Shelf Sci. 170: 173-185.

Pradit, S; Pattarathomrong, MS; Panutrakul, S (2013). Arsenic, Cadmium and lead concentrations in sediment and biota from Songkhla lake : a review. Procedia Soc. Behave. Sci. 91: 573-580.

Remaili, TM; Simpson, SL; Amato, ED; Spadaro, DA; Jarolimek, CV; Jolley, DF (2016). The impact of sediment bioturbation by secondary organisms in benthic bioassays : Implication for sediment quality assessment. Environ. Pollut. 208 (B): 590-599.

Ritchie, RJ; Mekinda, N (2016). Arsenic toxicity in the water weed wolffia arriza measured using pulse amplitudemodulation fluorometer (PAM) measurments of photo synthesis. Ecotoxicol. Environ. Saf. 132: 178-185.

Robbins, LJ; Swanner, ED; Lalonde, SV; Eickhoff, M; Paranich, ML; Reinhard, CT; Peacock, CL; Kappler,A; Konhauser, KO (2015). Limited Zn and $\mathrm{Ni}$ mobility during simulated ion formation diagenesis. Chem. Geol. 402: 30-39.

Schijif, J; Zoll, AM (2011). When dissolved is not truly dissolved- The importance of colloids in study of metal sorption on organic

matter. J. Colloid Interface Sci. 361 (1): 137-147.

Tomlinson, DL; Wilson, JG; Harris, CR; Jeffrey, DW (1980). Problem in assessment of heavy levels in estuaries and the formation of pollution index. Helgol Meeres Untersuchungen 33 (1-4): 566575 .

Wagner, T (2002). Late Cretaceous to early Quaternary organic sedimentation in the eastern Equatorial Atlantic. Palaeogeography, Palaeoclimatology. Palaeoecol. 179 (1-2): 113147.

Wedepohl, KH 1995. The composition of the continental crust. Geochim. Cosmochimica Acta 59 (7): 1217-1232, 1995.

Yao, MK ; Métongo, BS ; Trokourey, A ; Bokra, Y (2009). Assessment of sediment contamination by heavy metal in tropical lagoon urban area (Ebrié lagoon, Côte d'Ivoire). Eur. J. Scien. Res., 34(2):280-289.

Zhang, Y; Ji, X; Ku, T; Li, G; Jang, H (2016). Heavy metals bound to fine particulate from northern China induce season-dependent health risks : A study based on myocardial toxicity. Environ. Pollut. 216: 380-390.

Zheng, N; Liu, J; Wang, Q; Liang, Z (2010). Heavy metals exposure of children from stairway and sidewalk dust in the smelting district, northeast of China. Atmospheric Environ. 44 (27), 32393245 . 